\title{
Studies on the Heat Stability and Chromatographic Behaviour of the Scrapie Agent
}

\author{
By G. D. HUNTER AND G. C. MILLSON \\ Agricultural Research Council, Institute for Research on Animal Diseases, \\ Compton, Nerobury, Berkshire
}

(Received 9 June 1964)

\begin{abstract}
SUMMARY
Saline extracts of mouse-scrapie brain homogenates lost little infectivity when heated at $75^{\circ}$ for one hour. At higher temperatures, there was a progressive inactivation of the agent, although some of the infectivity still remained after heating at $100^{\circ}$ for one hour. The smooth shape of the inactivation curve suggests that the scrapie agent exists predominantly in a single heat-stable form. Ultrasonic disruption of scrapie mitochondrial suspensions altered the chromatographic behaviour of the scrapie agent in a way which suggests that the free agent is relatively small. The agent associates very readily with denatured proteinaceous material and because of this property it has not yet been possible to separate it effectively from contaminating tissue debris.
\end{abstract}

\section{INTRODUCTION}

Previous experiments with the scrapie agent passaged in mice (Hunter, Millson $\&$ Chandler, 1963) showed that the bulk of the agent in brain homogenates was associated with the particulate fractions of the cells. The highest infectivity was found in the mitochondrial-lysosomal fraction (Hunter, Millson \& Meek, 1964), although it was pointed out (Mould, Dawson \& Smith, 1964) that the concentration of the agent in the microsomal fractions of the brain cells was almost as great. None of these studies gave any clear indication of the nature of the association of the scrapie agent with the particulate fractions of the brain cells. Evidence is presented in this paper to show that the scrapie agent is not in fact comparable in size and density with mitochondria or lysosomes, but is a smaller agent that binds very firmly to tissue debris.

The experiments of Chandler (1963) confirmed to some extent that the mousepassaged scrapie agent was as resistant to chemical and physical attack as the sheep and goat agent had earlier been found to be (see review by Stamp, 1962). None of this earlier work, however, was of a quantitative nature, and the resistance of the agent to heat in particular was reminiscent of the behaviour of bacterial spores. It seemed possible that the agent might exist in more than one form, only one of which was heat resistant. However, the evidence presented in this paper suggests that the scrapie agent exists in a single heat-stable form. 


\section{METHODS}

Animal experiments. B.S.V.S. (bacterial susceptible, virus susceptible; Schneider, 1959) white mice were used in all experiments. Cases of scrapie were diagnosed as described previously (Hunter et al. 1963) following the criteria laid down by Chandler (1963) and by Pattison \& Smith (1963). Groups of at least six mice were used in all titration experiments, and all mice were inoculated intracerebrally with $0.02 \mathrm{ml}$. inoculum. ID 50 values, calculated according to the Kärber method (Parker, 1959), were all related back to the weight of the brain from which the relevant material was originally derived.

Application of heat to the scrapie agent. Six scrapie-affected mice were decapitated, the brains removed immediately and homogenized in a Potter-type homogenizer in physiological saline $(25 \mathrm{ml}$.). Readily sedimentable tissue debris was removed by centrifugation at $500 \mathrm{~g}$ for $10 \mathrm{~min}$. and rejected. A portion of the supernatant fluid $(0.5 \mathrm{ml}$.) was set aside and used for the preparation of saline dilutions as control material. One ml. portions of the supernatant fluid were placed in small tubes which were sealed in a blow-pipe flame. The tubes were heated for either $10 \mathrm{~min}$. or $60 \mathrm{~min}$. in water baths maintained at $50^{\circ}, 62.5^{\circ}, 75^{\circ}, 87.5^{\circ}$ or $100^{\circ}$, and in the case of the higher temperatures in baths of boiling $n$-butanol $\left(118^{\circ}\right)$ or xylene $\left(141^{\circ}\right)$. At the end of the required period, the tubes were removed from the liquid baths with tongs and cooled to room temperature as rapidly as possible. The tubes were cut open and the whole contents used for the preparation of saline dilutions in the usual way. Three dilutions only $\left(10^{-2}, 10^{-3}, 10^{-4}\right)$ were prepared for inoculation into mice and the infective titres calculated from the median incubation periods as described previously (Hunter et al. 1963).

In a further experiment, a crude scrapie mitochondrial suspension was prepared from the brains of three clinically affected mice as described previously (Hunter et al. 1964). This suspension was centrifuged at $40,000 \mathrm{~g}$ for $30 \mathrm{~min}$., and the pellet containing mitochondria, lysosomes, nerve-ending particles and a little myelin was re-homogenized in $10 \mathrm{ml}$. saline. This suspension was sealed in a glass tube and heated at $75-80^{\circ}$ for $60 \mathrm{~min}$. After cooling and opening the tube, coagulated material was sedimented at $500 \mathrm{~g}$ for $10 \mathrm{~min}$. A 'mitochondrial' fraction was sedimented from the supernatant fluid by centrifuging at $10,000 \mathrm{~g}$ for $15 \mathrm{~min}$, and finally a 'microsomal' fraction was prepared from the second supernatant fluid at $100,000 \mathrm{~g}$ for $90 \mathrm{~min}$. Saline dilutions of all three particulate fractions and of the original saline suspension and the final supernatant 'soluble' fraction were prepared for titration in mice.

Stability of the frozen scrapie agent. Saline dilutions of whole brain homogenates from scrapie affected mice were maintained between $-23^{\circ}$ and $-28^{\circ}$ after inoculation into mice. After 9 months had elapsed a second group of mice was inoculated with the same suspensions and the titrations of the scrapie agent in the two groups were compared.

Ultrasonic disintegration of scrapie mitochondrial suspensions. A crude suspension of scrapie mitochondria and lysosomes was prepared as described previously (Hunter et al. 1963) and sedimented at $10,000 \mathrm{~g}$ for $50 \mathrm{~min}$. The pellet was rehomogenized gently in $0.3 \mathrm{M}$-sucrose $(11 \mathrm{ml}$.), a portion retained for control dilutions, and the rest treated ultrasonically with a $60 \mathrm{~W}$. M.S.E.-Mullard ultrasonic 
disintegrator for 20 min., during which it was kept cool $\left(\ngtr 10^{\circ}\right)$ with an ice and water bath. A portion of the unfractionated ultrasonically treated material was retained for the preparation of saline dilutions, and the remainder was separated into a 'mitochondrial' fraction sedimented at $10,000 \mathrm{~g}$ for $50 \mathrm{~min}$., a 'microsomal' fraction sedimenting at $100,000 \mathrm{~g}$ in $120 \mathrm{~min}$., and a final 'soluble' fraction. Saline dilutions of all three fractions were prepared for titration in mice.

Action of a neutral detergent on the scrapie agent. A crude suspension of scrapie brain mitochondria was prepared as above from six scrapie-affected mice. After centrifugation at $10,000 \mathrm{~g}$ for $15 \mathrm{~min}$., one half of the sediment was suspended in saline and a portion used for the preparation of controls for mouse inoculation. The other half of the sediment was suspended in $0.01 \%$ Tween 80 (supplied by Honeywill and Stein Ltd., London, W.1) in 0.3 M-sucrose (12 ml.), homogenized and maintained at $2^{\circ}$ for $1 \mathrm{hr}$. A precipitate formed and was sedimented at $500 \mathrm{~g}$ for $10 \mathrm{~min}$. A 'mitochondrial' fraction was collected from the supernatant solution by centrifugation at $10,000 \mathrm{~g}$ for $15 \mathrm{~min}$., and a 'microsomal' fraction from the further supernatant solution was deposited by $100,000 \mathrm{~g}$ for $60 \mathrm{~min}$. Saline dilutions of these particulate fractions and of the final 'soluble' supernatant fraction were prepared and titrated in mice.

Chromatography of the scrapie agent. DEAE-cellulose was suspended in water and the fine particles removed by repeated decantation. Columns $1 \times 9 \mathrm{~cm}$., prepared and packed under positive pressure $(50 \mathrm{~mm}$. $\mathrm{Hg}$ ), were washed with about $50 \mathrm{ml}$. 0.01 N-NaOH and finally with 0.01 $\mathrm{M}$-phosphate buffer (pH 7.5) until the effluent became $\mathrm{pH}$ 7.5. Purified scrapie mitochondria were prepared as described previously (Hunter et al. 1963) and re-homogenized in 0.01 $\mathrm{m}$-phosphate buffer before application to the columns. Material derived from the equivalent of two mouse brains in $9 \mathrm{ml}$. was applied to each column, and eluted with successive $50 \mathrm{ml}$. portions of $0.01 \mathrm{M}$-phosphate buffer, $0.1 \mathrm{M}-\mathrm{NaCl}, 0.15 \mathrm{M}-\mathrm{NaCl}, 0.30 \mathrm{M}-\mathrm{NaCl}$, and $1.00 \mathrm{M}-\mathrm{NaCl}$; all the $\mathrm{NaCl}$ solutions were buffered with $0 \cdot 01 \mathrm{M}-$ phosphate buffer $(\mathrm{pH} \mathrm{7.5)}$. A portion of the purified scrapie mitochondrial suspension was subjected to ultrasonic treatment for $15 \mathrm{~min}$. before chromatography on DEAE-cellulose, under similar conditions. In one experiment a DEAE-cellulose column was loaded with ultrasonically-disrupted scrapie mitochondria as before, but the material eluted directly with $0.01 \mathrm{M}$-phosphate buffer was further separated into 'mitochondrial', 'microsomal', and soluble fractions by successive sedimentations at $10,000 \mathrm{~g}$ for $15 \mathrm{~min}$. and $100,000 \mathrm{~g}$ for $120 \mathrm{~min}$.

Calcium phosphate columns $(9 \times 1.8 \mathrm{~cm}$.) and buffers were prepared according to Taverne, Marshall \& Fulton (1958). Scrapie mitochondrial fractions, intact and disintegrated by ultrasonic treatment, were prepared as for the DEAE-cellulose chromatography; and material derived from the equivalent of one mouse brain was applied to the columns which were eluted with $0.01 \mathrm{M}$-phosphate buffer $(40 \mathrm{ml}$.) and then with successive $25 \mathrm{ml}$. portions of $0 \cdot 1 \mathrm{M}, 0.2 \mathrm{M}, 0 \cdot 4 \mathrm{M}$, and $1 \cdot 0 \mathrm{M}$-phosphate buffer.

Determination of protein was carried out by the Lowry method (Lowry, Rosebrough, Farr \& Randall, 1951). 


\section{RESULTS}

\section{Stability of the scrapie agent at different temperatures}

The results of the experiment of heating the saline extracts of scrapie mouse brain are summarized in Fig. 1. A slightly lower titre was obtained in the samples heated for 10 and $60 \mathrm{~min}$. at $62.5^{\circ}$ than in those heated at $75^{\circ}$. A sharp decrease in the titre of the agent occurred when extracts were heated at $100^{\circ}$, but a few cases of scrapie were observed in mice inoculated with a $10^{-2}$ dilution of material heated at $100^{\circ}$ even for $60 \mathrm{~min}$., and one mouse in the group inoculated with material heated at $118^{\circ}$ for $10 \mathrm{~min}$. also contracted the disease.

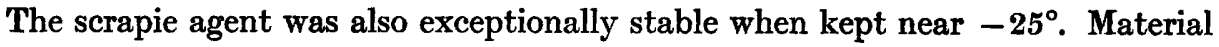
held for 8 months in physiological saline, conditions that would be considered severe for most viruses, showed a decrease in ID 50 value from 6.7 to 5.5 only.

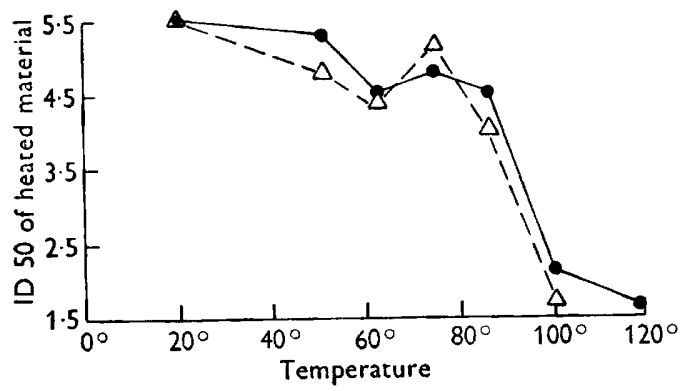

Fig. 1

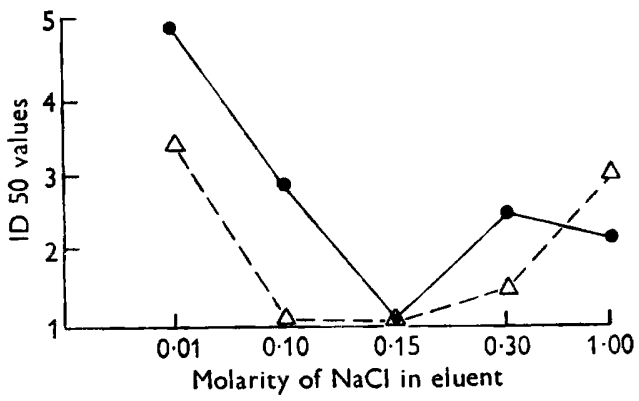

Fig. 2

Fig. 1. Effect of heat on saline extracts containing the scrapie agent. ID 50 values for the heated materials were determined by titration in mice as described in the text. - extracts heated for $10 \mathrm{~min}$; $\triangle \Delta_{-}-$-, extracts heated for $60 \mathrm{~min}$.

Fig. 2. Chromatographic behaviour on DEAE-cellulose of intact and ultrasonicallytreated scrapie mouse brain mitochondrial fractions (SMF) ID50 values for the various fractions were determined by titration as described in the text. Initial titre of the intact and ultrasonically-treated SMF $=4 \cdot 8 . \triangle--$ intact SMF; - - ultrasonically treated SMF.

\section{Effect of heat, ultrasonic treatment and Tween-80 on the sedimentation behaviour} of the scrapie agent

As shown in Table 1, all these treatments had the remarkable property of making the agent more readily sedimentable than previously, and in the case of heat and Tween-80 treatment, the bulk of the agent became sedimentable on an ordinary bench centrifuge. The experiments were terminated after 5-6 months only (Hunter et al. 1963), so that the titres were relatively low. None of the treatments had much effect on the overall infectivity of the extracts, but in each case no activity at all was found in the non-sedimentable soluble fraction.

\section{Chromatographic behaviour of the scrapie agent}

When the intact mitochondrial fraction was chromatographed on DEAEcellulose, only about $1 \%$ of the infective material was recovered, although nearly a half of the added protein was eluted (Table 2). However (after ultrasonic treatment). as shown in Fig. 2, the fraction that passed straight through the column with the 
Table 1. Sedimentation of the scrapie agent from extracts treated in various ways

\begin{tabular}{|c|c|c|c|c|c|}
\hline \multirow[b]{2}{*}{ Treatment } & \multirow{2}{*}{$\begin{array}{l}\text { Initial titre } \\
\text { (ID 50) }\end{array}$} & \multicolumn{3}{|c|}{$\begin{array}{c}\text { Titre in material successively } \\
\text { sedimented at }\end{array}$} & \multirow{2}{*}{$\begin{array}{c}\text { ID50 of } \\
\text { final 'soluble' } \\
\text { fraction }\end{array}$} \\
\hline & & $500 \mathrm{~g}$ & $10,000 \mathrm{~g}$ & $100,000 \mathrm{~g}$ & \\
\hline Heat $\left(75-80^{\circ}\right)$ & $\mathbf{5 \cdot 2}$ & $\mathbf{5} \cdot \mathbf{0}$ & $2 \cdot 0$ & $<1.5$ & $<1.5$ \\
\hline Ultrasonic & $5 \cdot 3$ & - & $5 \cdot 2$ & $1 \cdot 7$ & $<1.5$ \\
\hline Tween-80 (0.01 \%) & 4.5 & 4.5 & $\mathbf{3 \cdot 2}$ & $<\mathbf{1 \cdot 5}$ & $<1.5$ \\
\hline
\end{tabular}

initially applied buffer had lost no infectivity. Recovery of applied protein was about $75 \%$ in the case of the ultrasonically-treated material.

Very similar results (Table 3) were obtained when the scrapie agent was chromatographed on calcium phosphate. As in the case of the DEAE-cellulose run, much protein was retained when the intact mitochondrial fraction was used, and the small amount of scrapie agent that was eluted came in the fractions removed with the higher concentrations of phosphate buffer. The situation was altered in the

Table 2. Recovery of protein from intact and ultrasonically-treated mitochondriallysosomal fractions after chromatography on $D E A E$-cellulose

The total protein content of the material applied to the column was $24 \cdot 3 \mathrm{mg}$. in each case.

$\begin{array}{lcc}\text { Fraction eluted with } & \begin{array}{c}\text { Intact fraction } \\ \text { (mg. protein) }\end{array} & \begin{array}{c}\text { Ultrasonically- } \\ \text { (mg. protein) } \\ \text { (meted fraction }\end{array} \\ \text { 0.01 M-phosphate buffer } & \mathbf{3 \cdot 0} & 13 \cdot 0 \\ 0 \cdot 1 \mathrm{M}-\mathrm{NaCl} & 2 \cdot 7 & 2 \cdot 0 \\ 0 \cdot 15 \mathrm{M}-\mathrm{NaCl} & 1 \cdot 5 & 1 \cdot 0 \\ 0 \cdot 3 \mathrm{M}-\mathrm{NaCl} & 2 \cdot 0 & 1.4 \\ 1 \cdot 0 \mathrm{M}-\mathrm{NaCl} & 1 \cdot 5 & 0.0\end{array}$

Table 3. Chromatography of intact and ultrasonically-treated scrapie brain mitochondrial-lysosomal fraction on calcium phosphate

The intact mitochondrial fraction applied to the column had an ID50 value of 5.9 when titrated in mice; the ID 50 value of the ultrasonically-treated material (a separate experiment calculated after 6 months only) was $4 \cdot 7$.

$\begin{array}{ccc}\begin{array}{c}\text { Fraction eluted } \\ \text { with phosphate } \\ \text { buffer of } \\ \text { molarity }\end{array} & \begin{array}{c}\text { Titre (ID 50) } \\ \text { from intact } \\ \text { mitochondria }\end{array} & \begin{array}{c}\text { Titre (ID 50) from } \\ \text { ultrasonically- } \\ \text { treated } \\ \text { mitochondria }\end{array} \\ 0.01 & <1.7 & \mathbf{3 . 7} \\ \mathbf{0 . 1} & <\mathbf{1 . 5} & \mathbf{3 . 7} \\ 0.2 & \mathbf{2 . 4} & \mathbf{2 . 5} \\ 0.4 & \mathbf{3 . 5} & <\mathbf{2 . 7} \\ \mathbf{1 . 0} & \mathbf{3 . 3} & <2.5\end{array}$

case of the ultrasonically-treated fraction; again a substantial amount of the scrapie agent passed readily through the column. However, the overall recovery of infective agent was not as complete in the case of the calcium phosphate column as with DEAE-cellulose, even when ultrasonically-treated material was used. 
Table 4. Differential centrifugation of the fraction eluted from the DEAE-cellulose with 0.01 m-phosphate buffer

$\begin{array}{lcc}\text { Fraction } & \text { ID 50 value } & \begin{array}{c}\text { Protein con- } \\ \text { tent (mg.) }\end{array} \\ \begin{array}{c}\text { Ultrasonically-treated mito- } \\ \text { chondria applied to the column }\end{array} & \mathbf{5 \cdot 5} & - \\ \begin{array}{c}\text { Material eluted from the column } \\ \text { with } 0.01 \mathrm{~m}-\text { phosphate buffer }\end{array} & 4 \cdot 7 & - \\ \begin{array}{c}\text { Material in eluate sedimenting } \\ \text { at } 10,000 \mathrm{~g} \text {. }\end{array} & 4 \cdot 1 & \mathbf{2 \cdot 4} \\ \begin{array}{c}\text { Material in eluate sedimenting } \\ \text { at } 100,000 \mathrm{~g} \text {. }\end{array} & \mathbf{4 \cdot 2} & \mathbf{7 \cdot 7} \\ \begin{array}{c}\text { Supernatant fluid above } \\ \text { 100,000 } \mathrm{g} \text { sediment }\end{array} & \mathbf{3 \cdot 2} & \mathbf{2 \cdot 9}\end{array}$

In a further experiment where an ultrasonically-treated mitochondrial suspension from scrapie mouse brain was chromatographed on DEAE-cellulose, the material passing directly through the column in the $0.01 \mathrm{M}$-phosphate buffer was further fractionated by differential centrifugation (Table 4). The titres of the scrapie agent were now very similar in both 'mitochondrial' and 'microsomal' fractions. The column had, of course, removed some of the coarser debris, so that the 'microsomal' fraction sedimenting at $100,000 \mathrm{~g}$ was bulkier in this case than the 'mitochondrial' fraction. There appeared to be a slight overall loss in infectivity in this experiment when the agent was passed through the DEAE-cellulose column.

\section{DISCUSSION}

In the heating experiment (Fig. 1) it seems probable that the relatively small losses in infective agent observed when the saline extracts were heated at $50^{\circ}$ and $62.5^{\circ}$ were occasioned by enzymic attack. At these temperatures, some degradative enzymes would be inactivated only slowly. On the other hand, at $75^{\circ}$ most enzymes would be rapidly inactivated, although the even smaller losses of the scrapie agent observed at this temperature might also be due to the same cause. In fact, in repetitions of part of this experiment (see Table 1; also unpublished work), the loss of infective agent in extracts of scrapie heated to $75^{\circ}-80^{\circ}$ was negligible. It is interesting to note that substantial heat denaturation only sets in at temperatures near the melting temperature of DNA. However, it seems unlikely that the scrapie agent is a free nucleic acid since it has been found (Hunter \& Millson, unpublished work; Mould et al. 1964; Pattison \& Millson, 1960) that both RNase and DNase have only slight actions on the intact agent. When allowance is made for the probable action of enzymes, the heat denaturation curves are very smooth and the agent as a whole does exhibit remarkable resistance to the action of elevated temperatures. There does not seem to be any evidence here in favour of the existence of a heat-stable form of the agent, analogous to the bacterial spore; the results in fact suggest that the scrapie agent exists predominantly in a single form.

Previous experiments (Hunter et al. 1964) showed that when a cellular fractionation of mouse scrapie brain was done, the bulk of the infective agent was found in the mitochondrial-lysosomal fraction. Mould et al. (1964) pointed out that the smaller microsomal fractions contain almost as high a concentration of the scrapie 
agent as does the mitochondrial-lysosomal fraction; they further suggest that 'the mouse scrapie agent, if particulate, is extremely small and closely bound to tissue components'. Our chromatographic work would lead towards the same view, although there does not seem to be any direct evidence at present to suggest that the agent is smaller than particles of the 'picornavirus' group. It is nevertheless difficult to explain the altered chromatographic behaviour of the scrapie agent after ultrasonic treatment on any basis other than the release of the agent in a particulate form, or bound to particulate debris, of a size much smaller than the mitochondria and lysosomes. Moreover, removal of the coarser debris during the passage of the agent through DEAE-cellulose (Table 4) certainly leads to the elution of the agent in a form less readily sedimentable than previously. It almost seems that the sedimentation of the agent is a property of the debris to which it is bound, rather than to any property of the agent itself.

The avid binding of the agent to a denatured debris after heat and Tween treatment is remarkable, and makes the task of concentrating and separating the agent difficult. It again suggests that the agent is small, but it is still possible that the agent is, for instance, a small arbovirus with unusual surface properties. It is of interest here that the scrapie agent is sensitive to a considerable degree to the action of ether (Eklund, Hadlow \& Kennedy, 1963; Hunter \& Millson, 1964), and also to the action of other organic solvents (Hunter \& Millson, unpublished work), and it seems possible that lipid materials are concerned in maintaining the surface structure of the agent.

The results obtained when using calcium phosphate columns lead to the same general conclusions about the nature of the scrapie agent. Ultrasonic treatment seems to be equivalent to ether treatment (Mould, Smith \& Dawson, 1964), although ether treatment involves a greater loss in infectivity.

The authors are grateful to Dr W. S. Gordon, C.B.E., for his sustained interest and advice, to Mr A. Mackenzie and Mr P. Dennis for preparing the histological specimens, and they acknowledge the skilled technical assistance of Miss S. Langford and Mr M. Vockins. The work was supported in part by grants made to the Agricultural Research Council from U.S. Government funds administered under U.S. Public Law 480.

\section{REFERENCES}

Chandler, R. L. (1963). Experimental scrapie in the mouse. Res. vet. Sci. 4, 276.

Eklund, C. M., Hadlow, W. J. \& Kennedy, R. C. (1963). Some properties of the scrapie agent and its behaviour in mice. Proc. Soc. exp. Biol., N.Y. 112, 974.

Hunter, G. D. \& Milison, G. C. (1964). Further experiments on the comparative potency of tissue extracts from mice infected with scrapie. Res. vet. Sci. $5,149$.

Hunter, G. D., Millson, G. C. \& Chandler, R. L. (1963). Observations on the comparative infectivity of cellular fractions derived from homogenates of mouse-scrapie brain. Res. vet. Sci. 4, 543.

Hunter, G. D., Miluson, G. C. \& Meek, G. (1964). The intracellular location of the agent of mouse scrapie. J. gen. Microbiol. 34, 319.

Lowry, O. H., Rosebrough, N. J., Farr, A. L. \& Randall, R. J. (1951). Protein measurement with the Folin phenol reagent. J. biol. Chem. 193, 265.

Mould, D. L., Dawson, A. McL. \& Smith, W. (1964). The infectivities of brain-cell fractions from mice infected with Suffolk sheep-scrapie agent. Biochem. J. 91, 13 P. 
Mould, D. L., Smrth, W. \& Dawson, A. McL. (1964). The elution of scrapie brain tissue through calcium phosphate columns. Biochem. J. 91, 13 P.

Parker, R. C. (1959). Methods of Tissue Culture (3rd edition), p. 253. London: Pitman Medical Publishing Co. Ltd.

Patrison, I. H. \& Mrluson, G. C. (1960). Further observations on the experimental production of scrapie in goats and sheep. J. comp. Path. 70, 185.

Patrison, I. H. \& SмIтh, K. (1963). Histological observations on experimental scrapie in the mouse. Res. vet. Sci. 4, 269.

SchNeider, H. A. (1959). Genetic and nutritional aspects of experimental 'allergic' encephalomyelitis, in 'Allergic' Encephalomyelitis, ch. 3, p. 130. Ed. by M. W. Kies and E. C. Alvard. Oxford: Blackwell Scientific Publications, Ltd.

StaMP, J. T. (1962). Scrapie; a transmissible disease of sheep. Vet. Rec. 74, 357.

Taverne, J., Marshall, J. H. \& Fulton, F. (1958). The purification and concentration of viruses and virus soluble antigens on calcium phosphate. J. gen. Microbiol. 19, 451. 